\title{
舗装用アスファルトの耐候性に関する研究 一アスファルトの劣化機構についで-
}

堀 尾 哲一郎**, 今西 正 昭***, 山口尚 己***

Studies on the Weathering of Paving Grade Asphalts

- The Mechanism of the Weathering*-

by Tetsuichiro Horio**, Masaaki Imanishi*** and Naoki Yamaguchi*** tests.

Summary : The weatherabilities of several paving grade asphalts were studied by outdoor and accelerated

The following results were obtained.

(1) By the two tests, penetration decreased, while S.P. and asphaltene content increased.

(2) Having been weathered until the same penetration, the content of asphaltenes and the weight-loss of the outdoor test were more than those of the accelerated one.

(3) The changes of the surface of asphalts by weathering were different between the two tests.

(4) From these phenomena and our previous reports, we presumed the model of the weathering mechanism of asphalts (as typical visco-elastic material).

\section{1 緒 言}

我が国の経济は石油ショック以来, 高度成長から安定成長一 大きく方向転換され，省資源，省エネルギー，省力化などが強 く叫ばれており，工業材料の耐久力は重要な一因子といらこと になってきている。

工業材料の一つであるアスファルトも, 道路舗装, 防水工 事, 防食ライニングなど広く利用されており，その耐久力の利 用面への影翼は無視できない。

一方, 使用条件の過酷化, 寸なわち, 道路赫装に扔ける重量 化と高速化，防水工事における柔構造化，防食ライニングにお ける安全性の強化などとともに，各種競合材料の出現により， アスファルトは一つの試練にあっており，耐久性は重要な論点 の一っとなっている。

アスファルトの酎久性, 特に耐候性については, 古く Hubbard や Reeve ${ }^{1)}$ らの研究に始まり, Glozman ${ }^{2}$, Corbett ${ }^{3)}$,

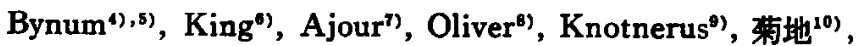
阪上 ${ }^{(1)} ら の$, 老化によるアスファルト組成変化の研究, Traxler ${ }^{12), 133}$, Fenijn ${ }^{14)}$ らの, 老化による物性変化に関する研究な ど，枚挙にいとまがないほど行われているが，アスファルトの 化学棒造が複雑である5え, 劣化現象に数多くの因子が関与し ているため，必ずしも全てが解明されているとはいえない。特 に,アスファルトの粘弾性との関連においてはほとんど論じら れていない。

アスファルトの耐候性について研究する場合，実際の条件に

* 昭和 50 年 2 月 10 日受理

** 丸萻石油侏式会社技術開発部 (100 東京都千代田区大手町1-5-3) Department of Technical Development, Maruzen Oil Co. Ltd. (No. 5-3, Ohtemachi 1-chome, Chiyoda-ku, Tokyo, Japan 100)

*** 丸蓄石油株式会社商品研究所 Products Development Center, Maruzen Oil Co., Ltd.
最も近い戸外ばく露試呀を行うのが理想であるが，何分にも長 期間を要するため，実験室内で戸外の劣化因子を集約した促進 ばく露試䥐で評価することが通常行われる方法である。しか し,この両者の相関についての見解は必ずしも確定しておら

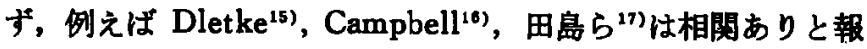
告しているのに対し, Oliensis'19), Fair ら ${ }^{19)}$ は否定的な報告を している。この理由はアスフォルトが粘弾性体であるため, 劣 化条件が変るとそれに対応するアスファルトの举動がそれぞれ

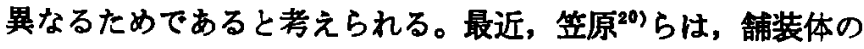
路面の深さによりアスフォルトの老化の状䈍が異なるといら報 告を行っているが,このことは上述のことと対応していると思 われる。

筆者らはアスファルトが粘弾性体であることを念頭におき， 以前からフスファルトの耐候性に関する一連の検討を行ってお り，その結果の大部分についてはすでに 報告している21) 24)。 今般さらに盏装用アスファルトの戸外試験と促進試験を実施 し，劣化の状態について考察を加えた。過去に得られた知見を 加味してアスファルトの劣化機構に関する一つの見解をまとめ たので以下に報告する。

\section{2 試料}

実験に用いた試料はストレートアスファルト3種, 触媒アス ファルト3 種, セミプローンアスファルト 1 種, 合計 7 種の舗 装用アスファルトである。これらの性状をまとめて Table 1 に示す。但し，促進試験においては実験装直の関係からこのう ち4 種類のみを用いた。

\section{3 実験方法}

3.1 試殹試料の作成

アスファルトを内径 $104 \mathrm{~mm}$, 周囲の高さ $0.6 \mathrm{~mm}$ の円简型 
Table 1 The Properties of Asphalt Sample

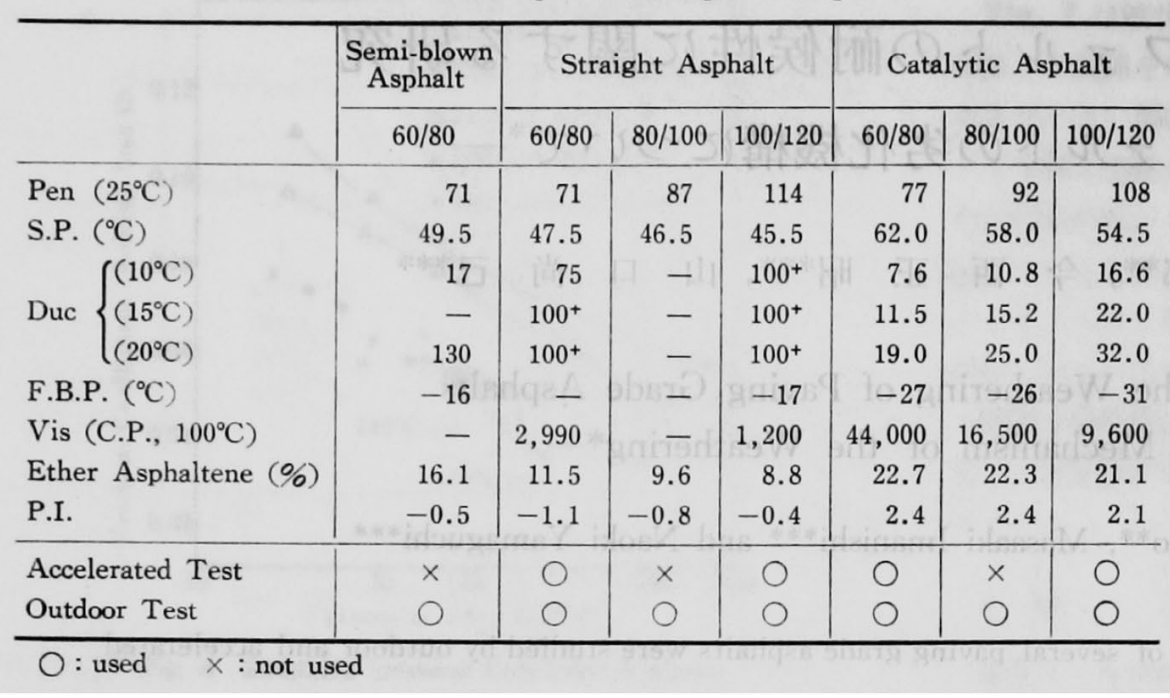

アルミニウム血に約 $5 \mathrm{~g}$ 採取し、これを熱少化しないように注 意しながら加熱溶解し，均一な薄膜にしたものを試験試料とし た。

\section{2 促進試駼}

促進試験は ASTM D 529-62 の Daily Cycle A 法を参考 に，以下に示す手順に従って行った。すなわち，島津式ウェザ ロメーターCW-DV 2 型の水平回転円筒台上に試験試料（同 一試料について各 7 枚）をのせ, 紫外線の連続照射と水の間久 的噴射を同時に行った。照射のサイクルは，22 時間までは照 射のみ, 22 時間以後は照射のみ 51 分, 照射と散水 9 分の条件 を1日 22 回紼り返えした。ばく露時間は $100 / 120$ で 800 時 間, 60/80で 300 時間である。この過程での試験温度は $60^{\circ} \mathrm{C}$ あり, 散水量は $0.5 \mathrm{l} / \mathrm{min}$ である。なお, 散水汕設備の関係 で上，工業用水を用いた。武倹の状況写真を Fig. 1 に示子。

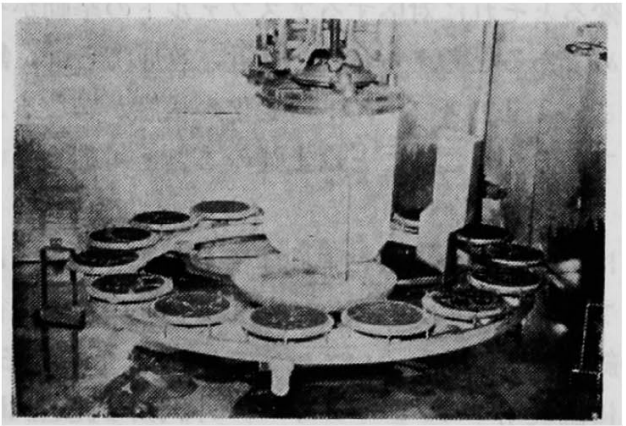

Fig. 1 Accelerated Test

\section{3 戸外試験}

戸外試験は高さ $1 \mathrm{~m}$ の水平な台上にアスファルト 1 種につ き 5 枚の試料をのせ， 1 年間戸外にばく露を行った。試験の状 況写真を Fig. 2 に示す。

\section{4 ばく露過程及びばく路後の試験項目}

ばく露過程及びばく露後の試料について以下の試験を行 。 た。なお, 戸外試験の場合には試料の量の関係からこのうち一 部の試険にとどめた。

- 重量测定

・表面貔察及び表面写真撮影

- 針入度 : JIS K 2530

-莗化点 : JIS K 2531

・アスファルテン：ジエチルエーテルを用いて不溶分と可溶

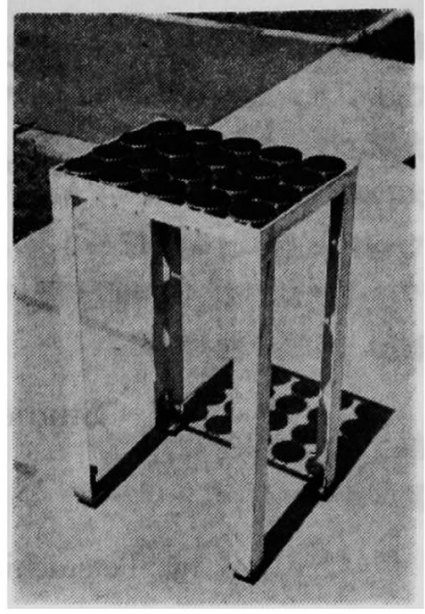

Fig. 2 Outdoor Test

分に別け，不溶分をアスフォルテン25) と した。一方，可溶分をマルテンとした。 ・マルテンの粘度 : ジェチルエーテル可溶分の 粘度 ${ }^{26)} 10$

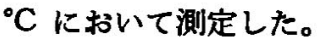

・マルテンの吸光度比 : ジェチルエーテル可溶分の赤外吸収 スペクトルをとり，主としてアスファル トの酸化により生じた $5.86 \mu$ の $\mathrm{C}=0$ の吸収と, 内部標準である $6.85 \mu$ の C-H 変角振動の吸収の比を吸光度比と して計算した。計算の例を Fig. 3 に示 す。

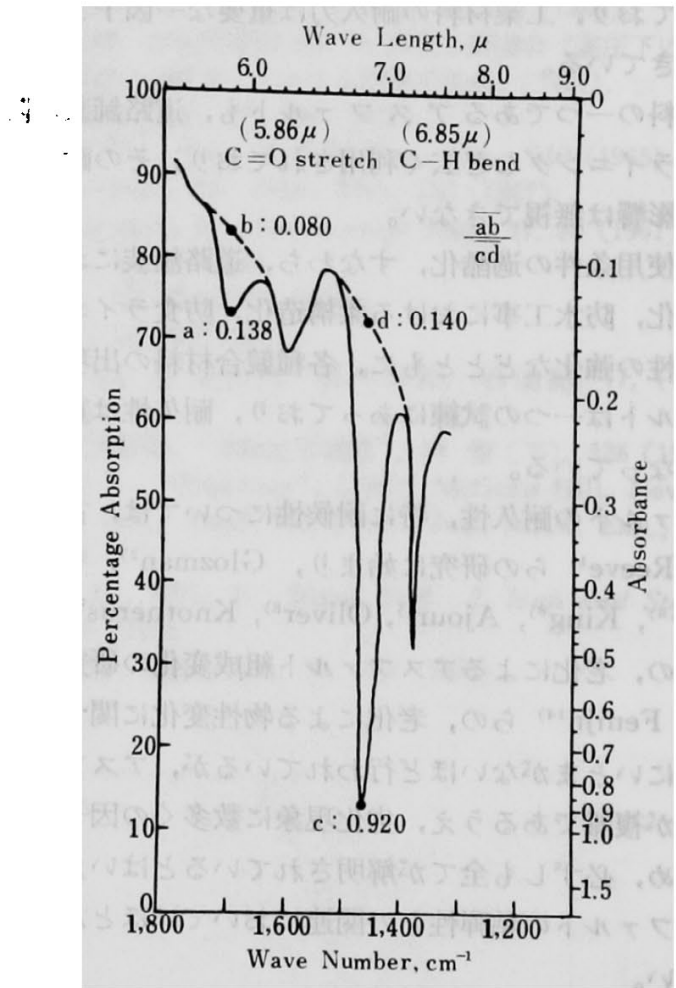

Fig. 3 The Example of the Calculation Method of the Ratio of Absorbance

\section{4 実験結果と考察}

耐候性試稀の過程及び終了後に得られた データをまとめて Table 2, 3 に示す。 
Table 2 Changes of Asphalt Properties after Weathering (Accelerated Test)

\begin{tabular}{|c|c|c|c|c|c|c|c|}
\hline & $\begin{array}{l}\text { Weathering } \\
\text { Time } \\
\text { (hr) }\end{array}$ & $\begin{array}{c}\text { Pen. } \\
\left(25^{\circ} \mathrm{C}\right)\end{array}$ & $\begin{array}{l}\text { S.P. } \\
\left({ }^{\circ} \mathrm{C}\right)\end{array}$ & $\begin{array}{c}\text { Ether Asphaltene } \\
\text { Content } \\
(\%)\end{array}$ & $\begin{array}{c}\text { Vis. of Maltene } \\
\text { (poise, } 10^{\circ} \mathrm{C} \text { ) }\end{array}$ & $\begin{array}{l}\text { Ratio of } \\
\text { Absorbance }\end{array}$ & $\begin{array}{c}\text { Weight Loss } \\
(\%)\end{array}$ \\
\hline \multirow{11}{*}{$\begin{array}{c}\text { Catalytic Asphalt } \\
100 / 120\end{array}$} & 0 & 108 & 54.5 & 20.2 & $1.16 \times 10^{5}$ & 0.025 & - \\
\hline & 10 & 72 & 61.5 & 21.1 & - & - & 0.15 \\
\hline & 22 & 63 & 63.5 & 22.1 & - & - & 0.38 \\
\hline & 50 & 59 & 64.5 & 22.5 & $2.16 \times 10^{5}$ & - & 0.61 \\
\hline & 75 & 56 & 66.0 & 22.6 & - & - & 0.33 \\
\hline & 100 & 52 & 67.5 & 23.0 & $2.32 \times 10^{5}$ & - & 0.20 \\
\hline & 150 & 38 & 69.0 & 25.3 & $2.76 \times 10^{5}$ & 0.080 & -0.77 \\
\hline & 300 & 36 & 70.0 & 25.7 & $3.36 \times 10^{5}$ & 0.088 & -1.52 \\
\hline & 500 & 27 & 75.5 & 26.5 & $4.87 \times 10^{5}$ & 0.105 & -2.83 \\
\hline & 650 & 26 & 78.0 & 27.1 & $5.90 \times 10^{5}$ & 0.121 & -3.19 \\
\hline & 800 & 24 & 80.0 & 27.9 & $8.15 \times 10^{5}$ & 0.130 & -3.71 \\
\hline \multirow{11}{*}{$\begin{array}{c}\text { Straight Asphalt } \\
100 / 120\end{array}$} & 0 & 114 & 45.5 & 9.0 & $5.55 \times 10^{8}$ & - & - \\
\hline & 10 & 69 & 49.0 & 10.3 & - & - & 0.35 \\
\hline & 22 & 58 & 50.5 & 11.2 & - & - & 0.32 \\
\hline & 50 & 54 & 54.0 & 11.7 & $7.66 \times 10^{8}$ & 0.018 & 0.49 \\
\hline & 75 & 52 & 55.0 & II. 8 & - & - & 0.55 \\
\hline & 100 & 46 & 56.0 & 12.3 & $8.36 \times 10^{6}$ & 0.030 & 0.43 \\
\hline & 150 & 34 & 57.0 & 14.8 & $1.12 \times 10^{7}$ & 0.043 & 0.18 \\
\hline & 300 & 32 & 59.0 & 16.2 & $1.30 \times 10^{7}$ & 0.074 & -0.17 \\
\hline & 500 & 25 & 61.0 & 18.0 & $1.61 \times 10^{7}$ & 0.085 & -0.26 \\
\hline & 650 & 23 & 62.5 & 18.8 & $1.88 \times 10^{7}$ & 0.101 & -0.33 \\
\hline & 800 & 21 & 63.0 & 19.1 & $2.69 \times 10^{7}$ & 0.102 & -0.50 \\
\hline \multirow{8}{*}{$\begin{array}{l}\text { Catalytic Asphalt } \\
60 / 80\end{array}$} & 0 & 77 & 62.0 & 23.7 & $1.21 \times 10^{5}$ & 0.023 & - \\
\hline & 22 & 52 & 65.5 & 24.1 & $2.10 \times 10^{5}$ & 0.033 & 0.30 \\
\hline & 50 & 43 & 71.0 & 25.1 & $2.53 \times 10^{5}$ & 0.044 & 0.53 \\
\hline & 75 & 39 & 73.5 & 25.5 & $2.39 \times 10^{s}$ & 0.053 & - \\
\hline & 100 & 37 & 75.0 & 25.9 & - & - & 0.35 \\
\hline & 150 & 31 & 78.5 & 26.8 & $2.74 \times 10^{5}$ & 0.070 & 0.19 \\
\hline & 200 & 28 & 80.0 & 27.5 & $3.41 \times 10^{5}$ & 0.074 & -0.57 \\
\hline & 300 & 26 & 81.0 & 28.6 & $4.22 \times 10^{5}$ & 0.080 & -1.14 \\
\hline \multirow{8}{*}{$\begin{array}{c}\text { Straight Asphalt } \\
60 / 80\end{array}$} & 0 & 71 & 47.5 & 11.5 & $7.50 \times 10^{\circ}$ & - & - \\
\hline & 22 & 42 & 54.0 & 14.1 & $9.36 \times 10^{6}$ & 0.017 & 0.31 \\
\hline & 50 & 39 & 54.5 & 14.8 & $1.17 \times 10^{7}$ & 0.019 & 0.44 \\
\hline & 75 & 36 & 56.0 & 15.7 & - & 0.025 & - \\
\hline & 100 & 33 & 57.0 & 15.5 & $1.31 \times 10^{7}$ & 0.026 & 0.50 \\
\hline & 150 & 29 & 59.5 & 16.1 & - & - & 0.54 \\
\hline & 200 & 26 & 60.0 & 17.5 & $1.50 \times 10^{7}$ & 0.044 & 0.38 \\
\hline & 300 & 24 & 61.0 & 17.8 & $2.10 \times 10^{7}$ & 0.046 & 0.20 \\
\hline
\end{tabular}

\section{1 針入度, 軟化点の経封変化}

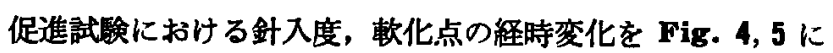
示す。ばく露時間が経過するに従い,アスフォルトの針入度は

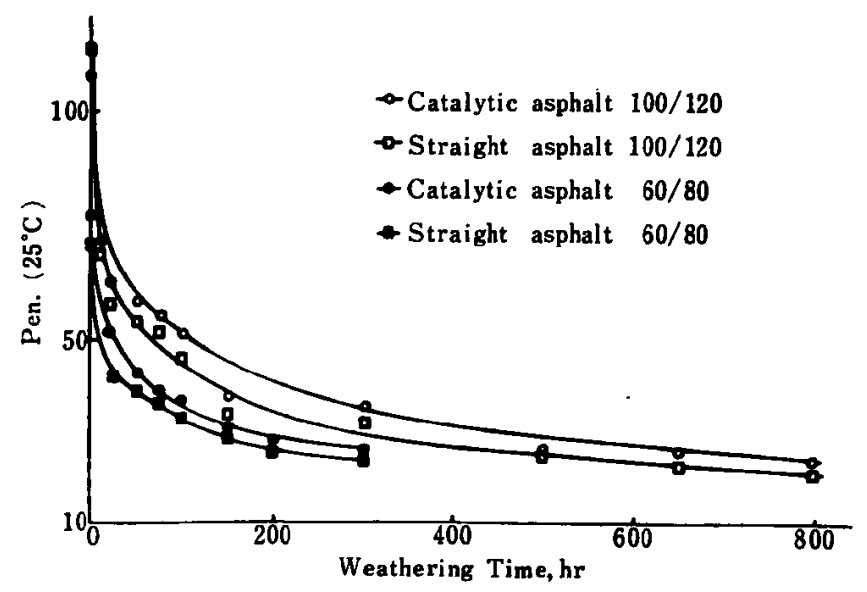

Fig. 4 Relationship between Pen. and Weathering Time (Accelerated Test)
低下し，軟化点は増大する。この傾向はばく露初期において著 しく，時間とともにその低下率は急速に小さくなっている。す なわち，促進試験におけるアスファルトの劣化は初期において 著しく，その後はおだやかに進むことを示している。このこと はばく露初期においては表面酸化がさかんにおこり，主として

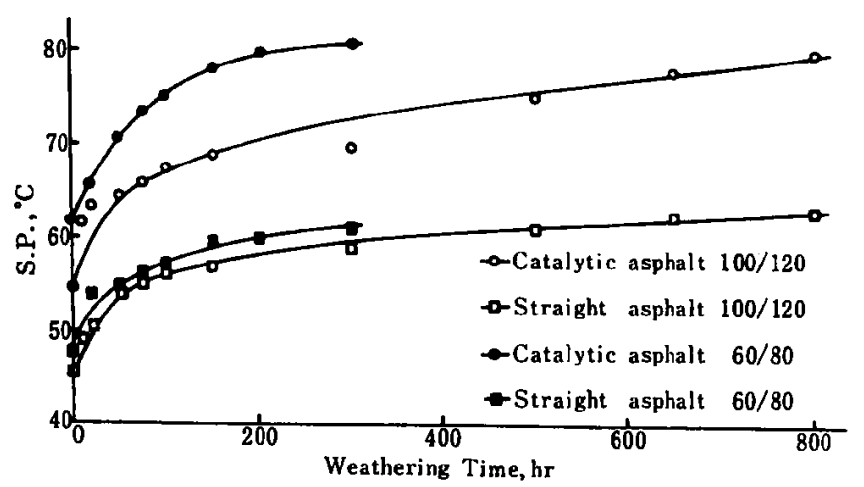

Fig. 5 Relationship between S.P. and Weathering Time (Accelerated Test) 
Table 3 Changes of Asphalt Properties after Weathering (Outdoor Test)

\begin{tabular}{|c|c|c|c|}
\hline & & $\begin{array}{c}\text { Pen. } \\
\left(25^{\circ} \mathrm{C}\right)\end{array}$ & $\begin{array}{c}\text { Ether } \\
\text { Asphaltene } \\
\text { (\%) }\end{array}$ \\
\hline $\begin{array}{c}\text { Straight Asphalt } \\
60 / 80\end{array}$ & $\begin{array}{l}\text { Original } \\
\text { After } 1 \text { Year }\end{array}$ & $\begin{array}{l}71 \\
27\end{array}$ & $\begin{array}{l}11.5 \\
19.3\end{array}$ \\
\hline$\underset{\mathbf{8 0 / 1 0 0}}{\text { Straight Asphalt }}$ & $\begin{array}{l}\text { Original } \\
\text { After } 1 \text { Year }\end{array}$ & $\begin{array}{l}87 \\
31\end{array}$ & $\begin{array}{r}9.6 \\
19.1\end{array}$ \\
\hline$\underset{100 / 120}{\text { Straight Asphalt }}$ & $\begin{array}{l}\text { Original } \\
\text { After } 1 \text { Year }\end{array}$ & $\begin{array}{r}114 \\
38\end{array}$ & $\begin{array}{r}8.8 \\
19.0\end{array}$ \\
\hline $\begin{array}{c}\text { Catalytic Asphalt } \\
60 / 80\end{array}$ & $\begin{array}{l}\text { Original } \\
\text { After } 1 \text { Year }\end{array}$ & $\begin{array}{l}77 \\
24\end{array}$ & $\begin{array}{l}22.7 \\
34.4\end{array}$ \\
\hline $\begin{array}{c}\text { Catalytic Asphalt } \\
\mathbf{8 0 / 1 0 0}\end{array}$ & $\begin{array}{l}\text { Original } \\
\text { After } 1 \text { Year }\end{array}$ & $\begin{array}{l}92 \\
30\end{array}$ & $\begin{array}{l}22.3 \\
34.0\end{array}$ \\
\hline $\begin{array}{c}\text { Catalytic Asphalt } \\
100 / 120\end{array}$ & $\begin{array}{l}\text { Original } \\
\text { After } 1 \text { Year }\end{array}$ & $\begin{array}{r}108 \\
34\end{array}$ & $\begin{array}{l}21.1 \\
32.0\end{array}$ \\
\hline $\begin{array}{c}\text { Semi-blown } \\
\text { Asphalt } \\
60 / 80\end{array}$ & $\begin{array}{l}\text { Original } \\
\text { After } 1 \text { Year }\end{array}$ & $\begin{array}{l}71 \\
29\end{array}$ & $\begin{array}{l}16.1 \\
30.5\end{array}$ \\
\hline
\end{tabular}

アスファルテンによる表面膜の生成があり，表面膜の生成後は 内部アスフォルトが保䒾されて劣化がおさえられることを示し ていると考えられる。また，針入度はばく露が進むにつれて一 定值に収れんするような㑯向が認められるが，軟化点の場合 は，元の性状の相違が後にも影县している。なお，戸外試験は 中間データがないので明確な㑯向を知ることはできないが，促 進試験と同様, ばく露初期におりる変化が大きいのではないか と予想される。

4.2 アスファルテン量, マルテンの粘度, 吸光度比の経時 変化

Fig. 6〜8に促進試験におけるアスファルテン量, マルテン の粘度, 吸光度比の経時的な变化を示す。ばく露が進むにつれ てアスファルテン量, マルテンの粘度, 吸光度比は増大してい き，その㑯向は針入度，軟化点の場合と同様，初期において值 の増加が著しい。すなわち、ばく露初期においてアスファルト は急激に酸化を受け硬化するのがわかる。

Fig. 9 は活く簬過程における針入度とアスフォルテン量の 閶係を戸外試験と促進試験で比較したものである。二つの試験 の間のデータを比校してみると同一針入度におけるアスファル テン量は明らかに戸外試験の方が増加している。この㑯向は舗 装用アスフォルトばかりでなく，ブローンアスフォルトの埸合

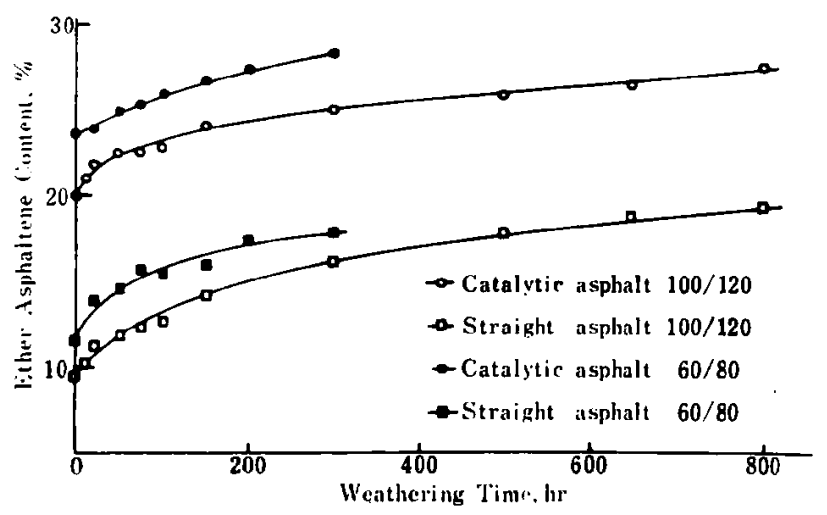

Fig. 6 Relationship between Ether Asphaltene Content and Weathering Time (Accelerated Test)

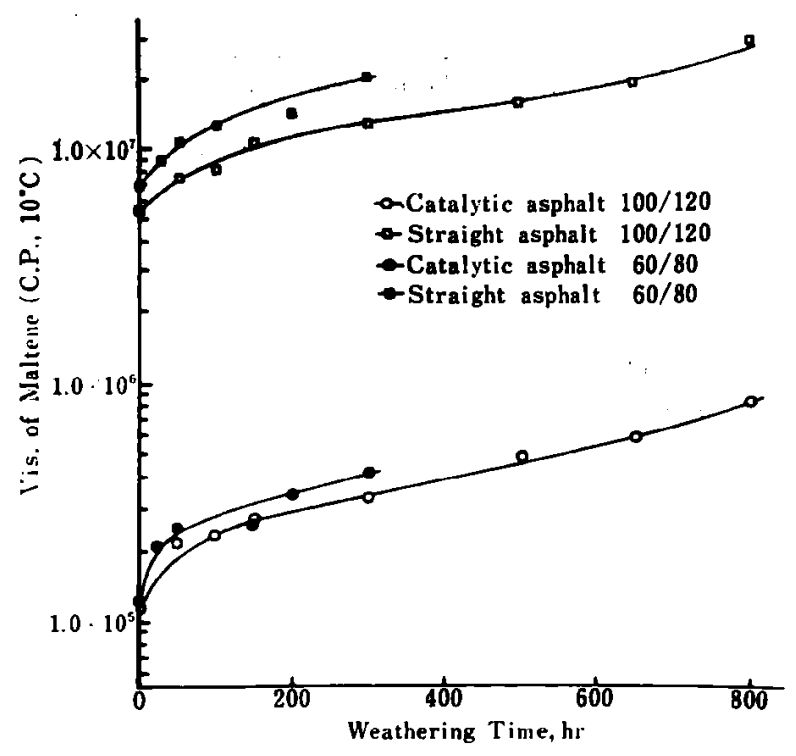

Fig. 7 Relationship between Vis. of Maltene and Weathering Time (Accelerated Test)

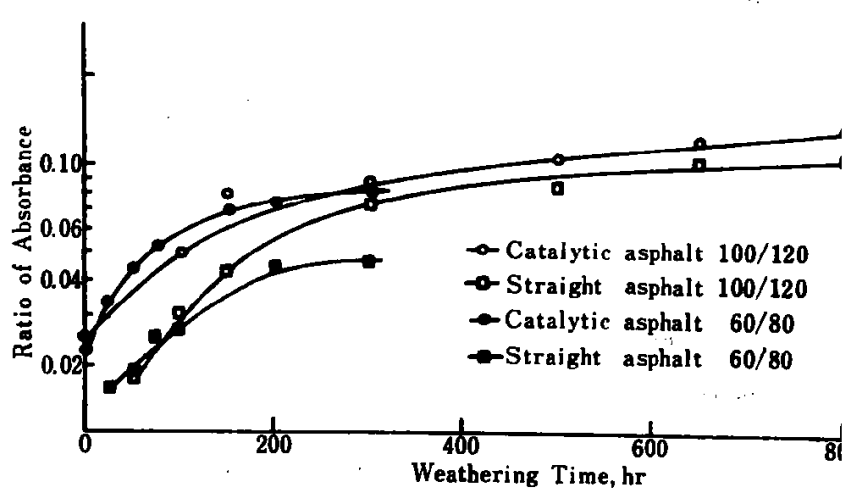

Fig. 8 Relationship between Ratio of Absorbance and Weathering Time (Accelerated Test)

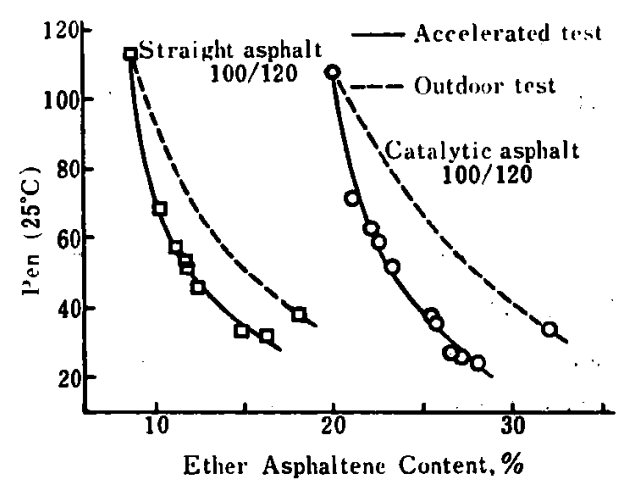

Fig. 9-(1) Relationship between Pen. and Ether Asphaltene Content (100/120)

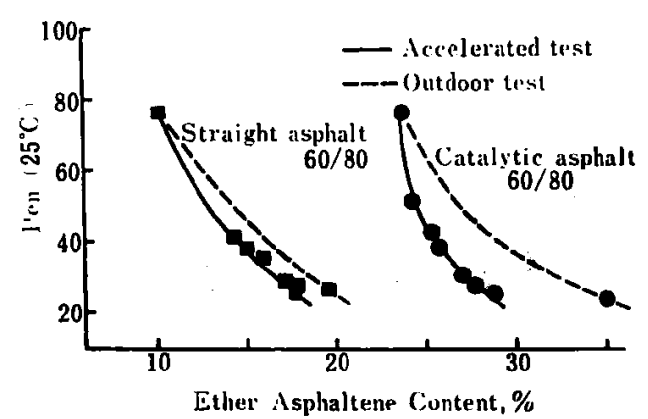

Fig. 9-(2) Relationship between Pen. and Ether Asphaltene Content (60/80) 


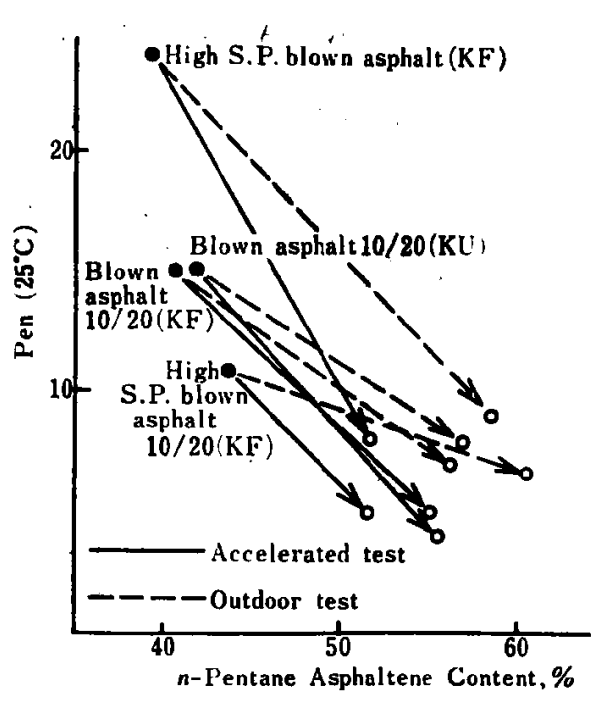

Fig. 10 Relationship between Pen. and n-Pentane Asphaltene Content (Blown Asphalt)

にも热められる。すなわち, 筆者らは以前, 一連のブローン アスファルトについても耐候性陚験を実施したが, この結果 Fig. 10 で示されるように同一針入度におけるアスファルテン 量 (n-ペンタン不溶分) は戸外試涘の方が多いというデータが 得られた。この事実は両試験におけるアスフォルトの少化機粠 が異なっていることを示唆していると考えられる。

4.3 アスファルトの重量の程時変化

Fig. 11 と 12 に促進試験と戸外試験における重量の経時变 化を示す。全体的な傾向としては，ばく露初期において重量が 増加し，ある期間が過ぎると減少に変り，あとは単調に減少す る。この傾向から考えて，重量の増加する因子と減少する因子 がある。堌加する因子としては空気中の酸素の酸化による含酸 素化合物の生成 ${ }^{27}$ が考えられ，減少の因子としては揮発性成分

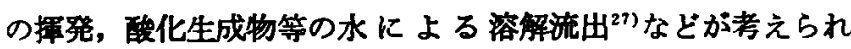
る。この两因子のつり合いにより重量变化曲線が決定されるわ けで，ばく露初期においては，酸化による重量增加因子が減少 因子にまさり，結果的に重量が増加するが，ある期間が過ぎる と酸化速度が落ちて, 揮発性成分の揮発や，酸化生成物の流出 が主となって直線的に減少するようになると考えられる。これ らの現象は King ${ }^{\text {() }}$ や笠原ら ${ }^{28)}$ の詳細な実験によっても示され ている。

アスファルトの種類による差をみてみるとストレートアスフ フルトの変化は小さく，触媒アスファルトの变化は大きい。こ れはストレートアスファルトの分子量分布が Altgelt ${ }^{29)}$ や筆

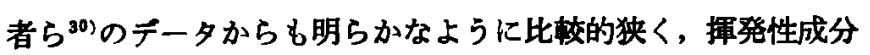
が少なく，ばく露初期の酸化は触媒アスファルトとほぼ同様に

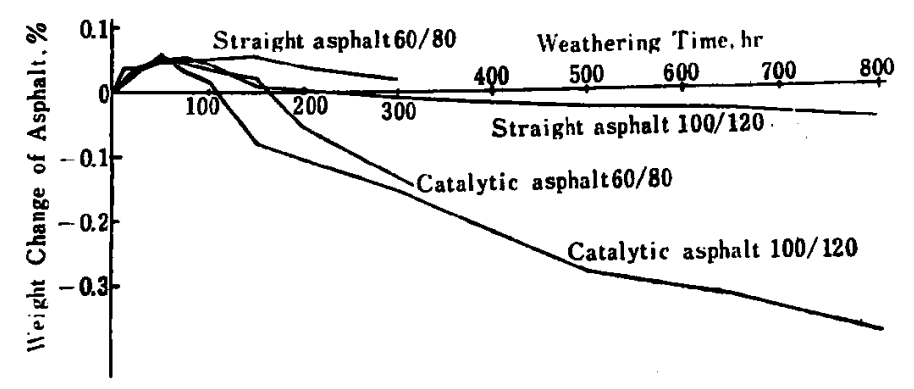

Fig. 11 Weight Change of Asphalt After Weathering (Accelerated Test)

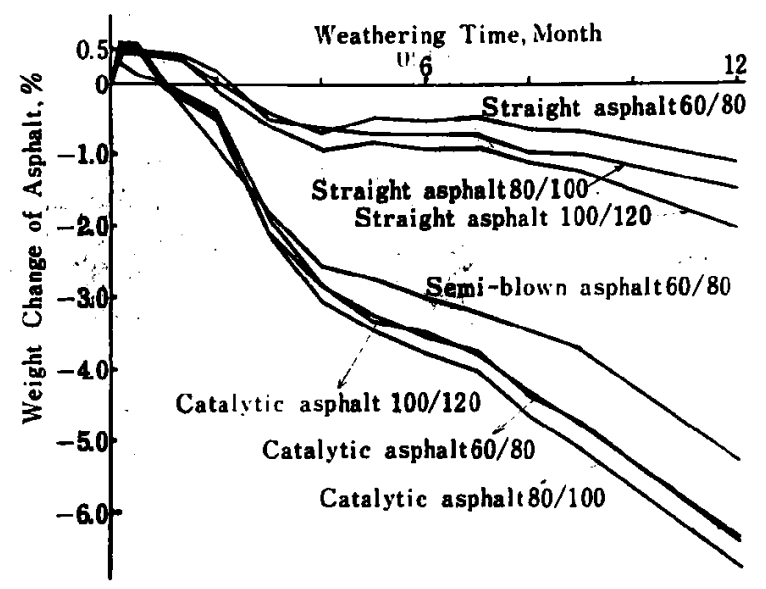

Fig. 12 Weight Change of Asphalt After Weathering (Outdoor Test)

受けるが, 重量減少の因子が小さいためと思われる。これに対 し，触媒アスファルトは触媒を使用したセミブローンアスファ ルトであり，分子量分布がストレートアスフナルトに比べて広 〈29，209，揮発等による損失が大きいためこのような結果にな ったと考えられる。なお，セミブローンアスフォルトも触媒ア スフォルトとほぽ同様の傾向がみられる。また戸外試験の場合 には季節の影鳘を受け，冬場の重量変化が小さくなっている。 すなわち, 戸外試験はばく管開始をいつにするかにより重量変 化や表面状腎の経時変化の㑯向が変る。このことは筆者らが舗 装用アスファルトについてばく路時期を変えて戸外ばく露試験 を実施し、詳細に検討した結果からも明らかである゙4。

4.4 ばく時のアスファルトの表面状想の变化

戸外試験と促進試験におけるアスファルトの表面状態の变化 を経時的に見るため，写真振影を行った。同種類のアスファル ト（すなわちストレートアスファルト同志, 触媒アスファルト 同志) ではグレードが異っても変化傾向に大差がないので, 代 表例としてストレートアスファルト100/120 と触媒アスファル ト100/120 の戸外試験と促進試験の結果を Fig. 13, 14 に示 す。両試殹で变化の状況が異っており, 劣化の進み力が異なる ことを示唆している。

一般にアスフォルトはばく露開始後柴外線照射，水の影響な どによる急激な環境の変化を受け，その变化に対応するカがア スフォルトの表面において一様でないため，小さな繑や凹凸を 生じる。その後表面における収縮応力が高して小さな割れ目に 発展する。そしてアスフォルトの硬化と収縮現象に伴う応力は 全てこの小さな割れ目に集中して，割れ目の長さと深さが増 し，最後にアルミ板に達する。この過程においてストレートア スファルト100/120はゾル型アスフォルトであるため流動性が あり, き裂の発生が非常に少ないのに対し, 触媒アスファルト 100/120 は製造過程でセミブローン処理を受けたゲル型アスフ フルトであるため, 全体の流動がおきにくく，き裂の発生がい たるところにみられきっ甲状になっている。尹外試験と促進試 験を比較してみると，流動性のあるストレートアスファルト 100/120 で汕両試験とも初期に薄い劣化皮膜ができているが, 戸外試験ではその後アスフォルト全体の流動化がおき，膜の存 在が消娍し，膜上にあった凹凸模様に開係のないしわが発生し ているのに対し，促進試験では表面の劣化膜がますます強固に 進行し, 内部アスフォルトの保蓝首のようになっているのがわ 


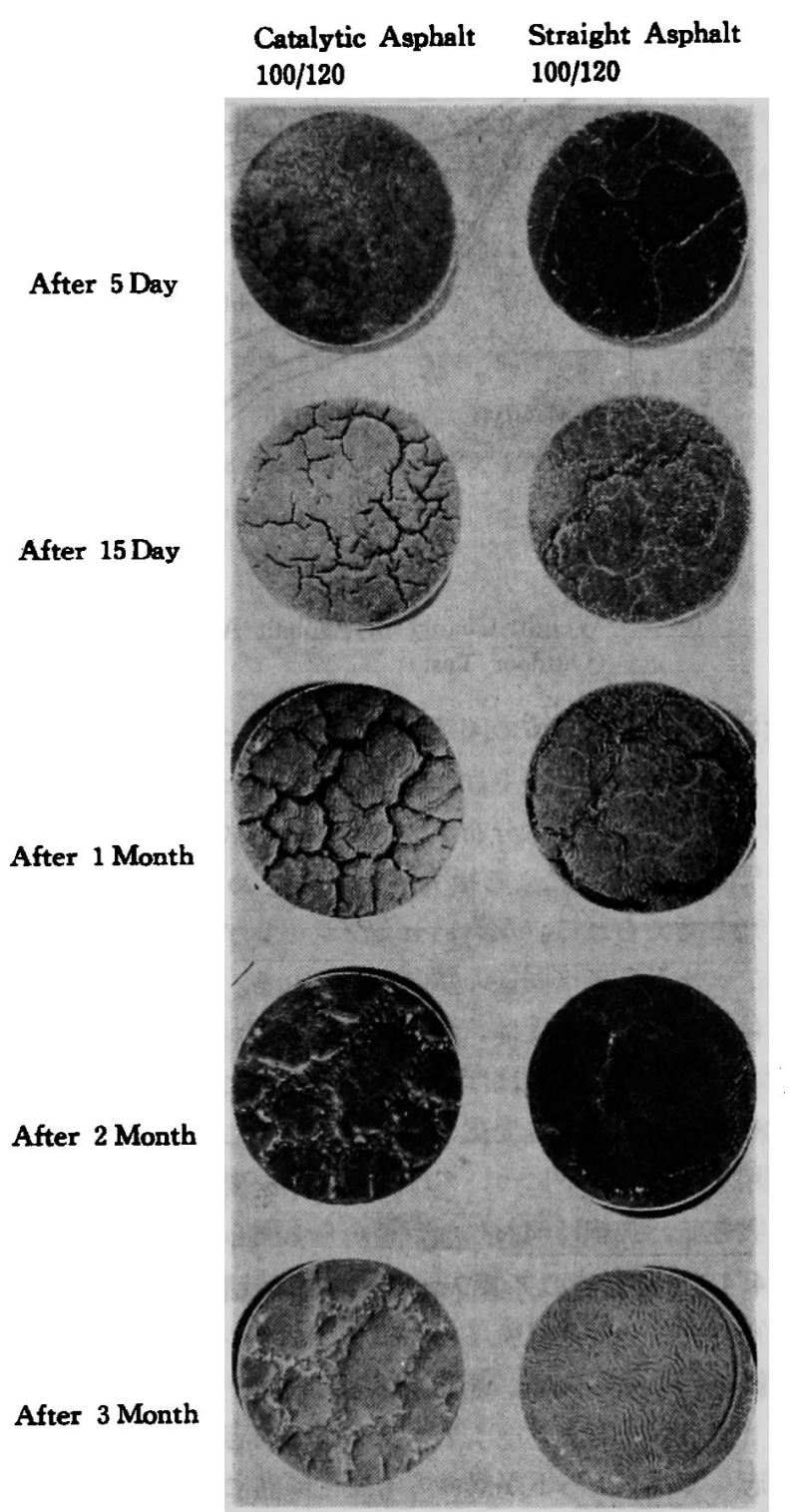

Fig. 13 Change of Sample Surface during the Outdoor Test わる。

一方，触媒アスフォルト100/120 の方も劣化条件の違いが表 面に現れておす，条件のきびしい促進試験の方がきっ甲が小さ く,数も多いとともにストレートアスファルト100/120の場合 と同様固い劣化膜が表面をおおっていくのがみられる。この表

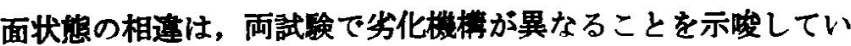
ると思われる。

\section{5 少化滕樌の推定}

アスファルトの耐候性を研究する場合，いちばん理想的な方 法は自然条件下にアスファルトをばく露し，その劣化状热をみ る戸外試験であることは論を待たない。しかしこの方法は何分 にも時間がかかりすぎ,成果が得られるまでにその研究自体が が陳腐になってしまらこともありらる。この久点をおぎならた め，室内で戸外における劣化条件を集約した促進試験を行い， 戸外における場合の推定を行うのが一般的である。筆者らは以 前からアスファルトの耐候性に関する一連の研究を行ってお り 21) 24)，その一桭として㬨装用アスファルトの戸外試験及び 促進試䀫を実施した。その結果，前述したよ5に戸外試験と促 進試硂ではまずアスファルテンの増加量に差があり，同一針入 度で比较すると戸外試駼の方がアスファルテンの増加量が大き くなることを確かめた。また,アスファルトの表面状稳の恋化

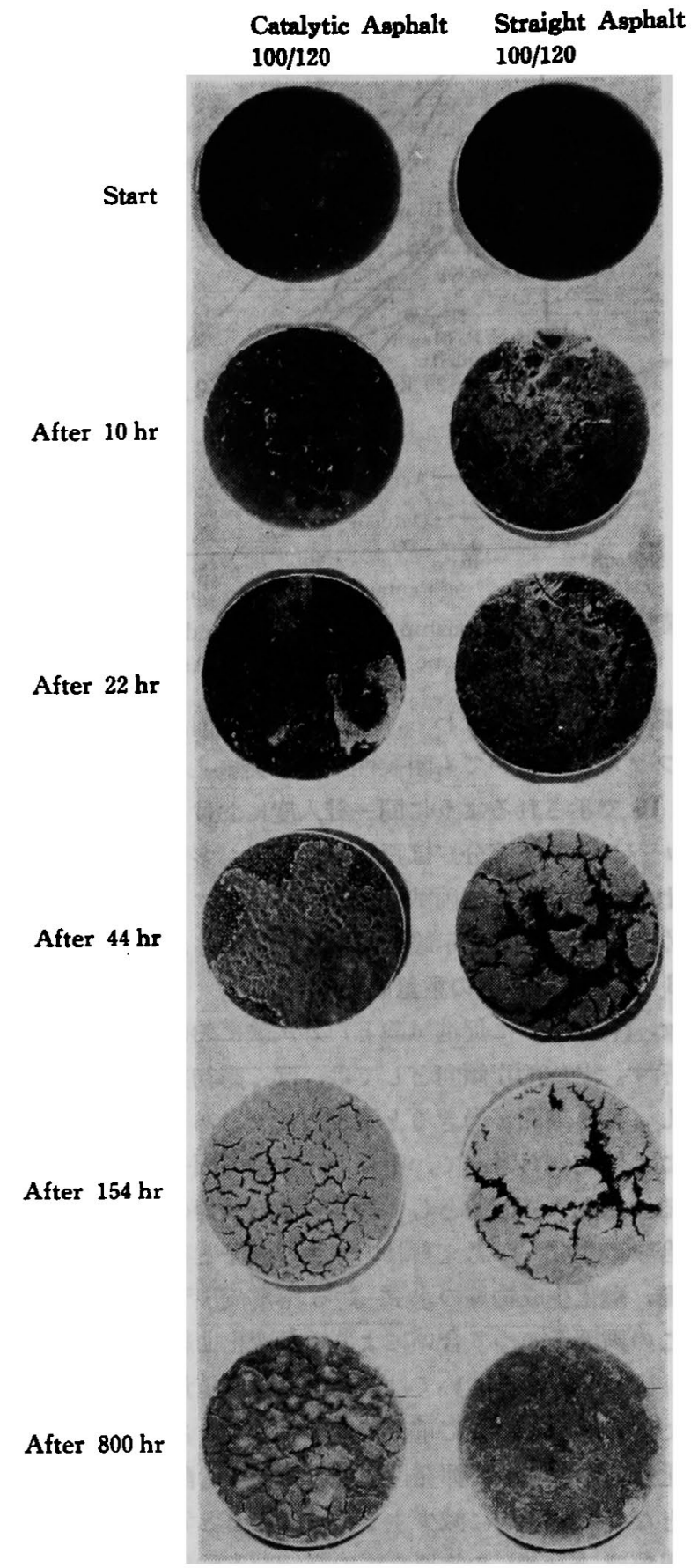

Fig. 14 Change of Sample Surface during the Accelerated Test

を経時的に舅察してみると，やはり戸外試験と促進試験で表面 劣化の進み具合が異なることが判明した。これらの結果を考瓦 に入れて,アスファルトの重量変化の傾向を針入度と対比し整 理したところ Fig. 15 のような結果が得られた。すなわち， 戸外試験は促進試験に比へて同一針入度における重量変化が大 きくなっており,このデータからも両試験法でアスファルトの 劣化機構に差があることが判った。これら多くのデータから考 えて我々はアスファルトの劣化機構に関し, Fig. 16 のモデル が妥当であると推定した。

すなわち，均一なアスファルト膜は，光と酸素などにより表 面が酸化され，酸化物の生成や重合によるアスファルテンの生 成が表面付近におきる。一方，揮発性成分は徐々に揮発すると ともに, 酸化物等の水可溶性成分も水に溶解して流出する ${ }^{27)}$ 。 このような現象のため, 表面付近は著しくアスファルテン過剩 になってくる。そしてアスファルト表面とアスファルト内部と 
のこの䈨度こう配が推進力となり，アスファルテンとマ ルテンの相互移助がおこり，浱度こう配をなくす方向 に現象が進む。この二つの現象，すなわち表面における アスファルテンの増加（劣化速度と関連する）と内部一 の拡散（移功の容易さと関係する）は動的平衡関係にあ りそれぞれの大きさによりアスフォルトの硬化と組成 との関係は左右される。促進試験と戸外試験の劣化機搆 の相違はこの機構により説明される。すなわち，促進試 倹の場合には，急激な劣化条件下におかれるため，表面 におけるアスフォルテンの生成のはやさがアスフォルテ ンの内部拡散のはやさにまさり，その結果, アスファル

ト表面にアスファルテンを主成分とした劣化皮膜が形成され る。この皮膜が内部アスファルトの保諨膜のよ5な倾きをし て, 各種劣化因子が内部アスファルトに作用するのを防ぐと同 時に, 内部アスフォルトの流動による表面への露出を阻止す る。そして,たわみ性の少ないアスファルテン皮膜は, 温度変 化等による伸縮にたえられずき裂が発生すると部分的に急速に 下部まで発展する。従ってアスファルテンの増加は表面だけに おこり，全体的な生成は少ない。これに対して，戸外試験の場 合には条件が温和なため，アスファルテン皮膜が形成される前 に内部アスフォルトが流動して表面に露出し劣化を受ける。こ のため, アスフォルト全体が均一に劣化を受け、アスフォルテ ンの生成量, 揮発性成分の揮発は全体的に均一におこるととも に, その量は促進試唡の埸合より多くなる。なお, 劣化皮膜は 光がアスファルト中に作用を及ぼすとされている数十ミクロン 程度の厚さ ${ }^{31)}$ と考えるのが妥当であるが，確諗はしていない。 いずれにしろ上記のことは, 試験前後のアスファルテン含有 量ばかりでなく, ばく露過程におけるアスファルトの表面状態 や, 重量変化の傾向からも率付けられる。これらの現象はアス フォルトが典型的な粘弾性体であるためにおこるものであり， 促進試験と戸外試検との関係にとどまらず, アスフォルトの種 類が異なる場合, アスファルトの膜厚が異なる場合にも現われ るはずである。従ってアスファルトの劣化現象を考える場合，

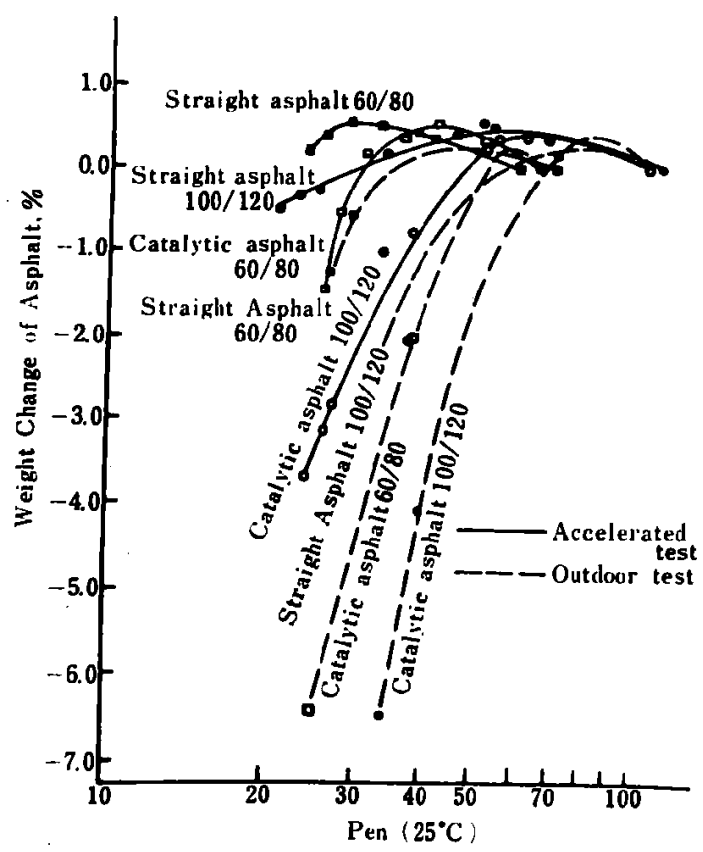

Fig. 15 Relationship between Weight Change and Pen.

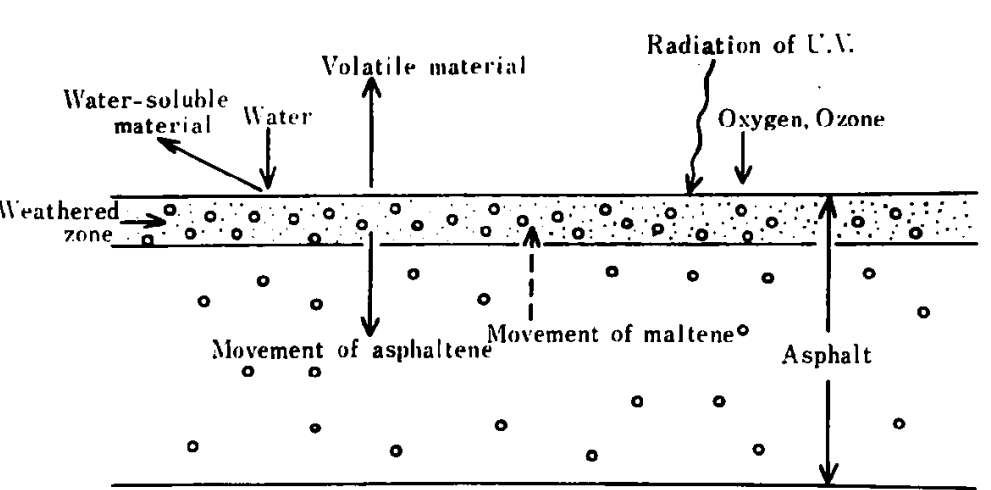

Fig. 16 Presumed Model of Weathering Mechanism

この劣化機構を十分念頭におかなければならないと思われる。

\section{5 結論}

舗装用アスフォルトの戸外試験と促進試験を実施し，両試験 で得られたデータを比較検郡した。その結果，全体的には両試 験の㑯向は一致していたが, アスファルテンの生成量, 表面の 経時的変化, 重量変化の傾向が両試験の間で相睡が見られ，こ の結果からアスファルトの劣化機㯪をモデル的に推定した。戸 外試験と促進試験のこのような相違は，アスファルトが粘弹性 体である故におこると考えられ，今後促進試験により自然条件 下の少化を推定する場合このことを十分考虑しなければならな いと思われる。

\section{引用文㗅}

1) Hubbard, P. et al., Ind. Eng. Chem., 5, (15), (1913).

2) Glozman, E.P., Akhmetova, R.S., Khim. Technol. Topl. Masel., 15, (5), 36 (1970).

3) Corbett, M.J., Lawson, G.J., Chem. Ind., 26, 866 (1970).

4) Bynum, D., Traxler, R.N., Parker, H.L., Ham, J.B., J. Inst. Petrol., London, 56, 147 (1970).

5) Bynum Jr., D., Traxler, R.N., Proc. Assoc. Asphalt Paving Technol., 39, 683 (1970).

6) King Jr., W.H., Corbett, L.W., Anal. Chem., 41, 580 (1969).

7) Ajour, A.M., Wiss. Z., Tech. Univ. Dresden, 18, 707 (1969).

8) Oliver, J.W.H., Gibson, H., Am. Chem. Soc., Div. Petrol. Chem., Prepr., 16, D 60 (1971).

9) Knotnerus, J., ibid., 16, D 37 (1971).

10) 菊地 5 , 石油誌, 4, (11), 850 (1961).

11) 阪上5, 石油䂼, 8, (10), 488 (1965).

12) Traxler, R.N., Scrivner, F.H., Am. Chem. Soc., Div. Petrol. Chem., Prepr., 16, D 102 (1971).

13) Traxler, R.N. et al., Proc. Assoc. Asphalt Paving Technol., 42, 126 (1973).

14) Fenijn, J., Erdöl Kohle, Erdgas, Petrochem., 23, 428 (1970).

15) Dletke, K., Bitumen, Teere, Asphalte, Peche, 8, 54 (1957).

16) Campbell,P.G. et al., Mater. Res. Stand., 2, 988 (1962).

17) 田島 5 , 石油竧, 3, (11), 888 (1960).

18) Oliensis, G.L., Am. Soc. Test. Mater., Spec. Tech. Pub., No. 94, 100 (1949).

19) Fair, W.F. et al., ibid., No. 94, 109 (1949).

20）笠原5, 石油誌, 18, (1), 30 (1975).

21）堀尾施，丸普石油挂報，(11)，11 (1966).

22) 堀尾ら，丸䔔石油挂報， (13)，32 (1968).

23) 堀尾与，丸菩石油技報，(15), 23 (1970).

24) 堀尾5, 丸善石油技報, (18), 27 (1973).

25) K.V.B.B. 1940, N-1031-V 10; Public Road, 21, 1 (1940).

26) Labout, J.W.A. et al., Anal. Chem., 28, 1147 (1956).

27) Strieter, O.G. et al., J. Res. Nat. Bur. Stand., 16, 481 (1936)など.

28) 笠原与, 石油誌, 17，(6), 478 (1974).

29) Altgelt, K.H., Die Makromolekulare Chemie, 88, 75 (1965).

30）上田, 山口, 秋原, 未発表.

31) Dickinson, E.J., Nicholas, J.H., Baos-Traube, S., J. Appl. Chem., 8, (1958) など. 